\title{
RESEARCH PAPER \\ Factors that influence the use of contract farming by southern Chilean farmers
}

\author{
Liliana Morales ${ }^{1}$, Rodrigo Echeverría ${ }^{2}$, and María del V. Barrera ${ }^{3}$ \\ ${ }^{1}$ Facultad de Ciencias Agrarias, Escuela de Graduados. ${ }^{2}$ Instituto de Economía Agraria. ${ }^{3}$ Instituto de \\ Ciencias Sociales. Universidad Austral de Chile, Casilla 567, Valdivia, Chile.
}

\begin{abstract}
L. Morales, R. Echeverría, and M. Barrera. 2013. Factors that determine the use of contract farming by southern Chilean farmers. Cien. Inv. Agr. 40(1):43-53. Unlike in the central zone of Chile, the use of contract farming (CF) is uncommon in the southern regions of the country, and few studies have attempted to explain this situation. The objective of this study was to analyze the factors that influence the use of CF in southern Chile. The methodology consisted of two approaches: a quantitative approach, wherein a multinomial logit model was applied to data obtained from questionnaires completed by 384 southern producers, and a qualitative approach that included in-depth individual interviews with professionals, officials of public institutions, and producer focus groups. The main results show that producers with high educational levels, large farms, and production oriented toward the export market who are located in areas with a high concentration of neighbors using $\mathrm{CF}$, who belong to organizations, and who need technical assistance from agribusiness firms are highly likely to use a CF system. However, despite the individual effect of each factor, their combined effect is related to the highest use of CF. Moreover, the lack of a positive relationship between risk-averse farmers and the use of contracts could be a sign of a problem in the way the contracts are established in southern Chile.
\end{abstract}

Key words: Contract farming, multinomial logit model, focus groups, interviews.

\section{Introduction}

Contract farming, a business model by which farmers and buyers establish pre-agreed supply agreements, dates back to the $19^{\text {th }}$ century (Vermeulen and Cotula, 2010). Today, contract farming $(\mathrm{CF})$ is used to varying degrees in almost every country in the world. For example, $\mathrm{CF}$ is

Received June 15, 2012. Accepted January 11, 2013. Corresponding author: rodrigoecheverria@uach.cl intensively used by livestock producers in the USA, by most maize and soybeans producers in India, and by a large number of rice producers in China (Guo et al., 2007; Eaton and Shepherd, 2001; Da Silva, 2005; Vermeulen and Cotula, 2010; Prowse, 2012). CF has been a key factor in promoting the production of high-value products, such as exportables. For example, the successful experience of Zimbabwe, which exports flowers, asparagus, sweet corn and chilies to several countries, is mainly due to the use of contract farming (Masakure and Henson, 2005; Heri, 2000). 
The aim of CF is to generate oral or written agreements that provide benefits for the two parties involved, i.e., for farmers and agribusiness firms. For example, firms can provide technical assistance to farmers to ensure that the products meet the quality requirements required by the target markets. Additionally, prices can be settled in advance, so both parties can forecast their expected benefits, thereby reducing their risk. In other cases, farmers can have access to credits provided by the firms, so that they can enter into or stay in business, while the firm ensures that it will receive the required production. Moreover, the use of CF reduces transaction costs (e.g., lower costs of settling with farmers), reduces input unit costs through economies of scale, and provides access to land that firms would otherwise have to buy (Eaton and Shepherd, 2001). On the other hand, a disadvantage of $\mathrm{CF}$ is that the agribusiness firms are generally in the dominant position, which can lead to abusive clauses or asymmetrical distribution of earnings (Singh, 2002).

Despite the advantages that CF offers, its adoption has been uneven in some countries. For example, although CF in Chile has been used extensively by the export-oriented agricultural sector, nonexporting farmers have relied on traditional ways of marketing their products. In fact, according to the agricultural census of 2007 (INE, 2007), 48\% of Chilean farmers who produce for the export market use $\mathrm{CF}$, while only $3 \%$ of farmers who produce for the domestic market use this system. The use of CF in Chile is also spatially unbalanced. Among the farmers who use $\mathrm{CF}$ and are located in the central zone (from the Valparaíso Region to the Bío-Bío Region), 51\% were export-oriented producers and $12 \%$ were non-exporters. However, among the farmers located in the southern regions (in the Araucanía Region and further south), 28\% of export-oriented farmers use $\mathrm{CF}$, while only $0.8 \%$ of non-exporters use this contract system.

The literature reports several factors that influence the adoption and use of contract farming. These factors are related to the farmer (e.g., gender, educational level, risk aversion), the farm (e.g., farm size, land tenure system, farm production) and some out-of-farm elements (e.g., the effect of neighboring producers). Gender is a relevant variable because, in general, contracts are signed by the heads of families, who in many cases are men (Eaton and Shepherd, 2001). The educational level of farmers is considered important because better-educated farmers are better able to negotiate with agribusiness firms (Chiriboga et al., 2007). The farmer's risk is also a key variable in the use of CF because farmers minimize their risk through contracts. For example, farmers who produce for the export market are less risk averse than domestic-market-oriented farmers, and therefore, the use of CF could help to reduce the risks involved in the more complex process of selling products abroad (Key and McBride, 2003).

Among the farm-related factors, the land tenure system is another critical factor. In general, when farmers own their land (instead of renting it), they can offer the land as a real guarantee, so banks or agribusiness firms will be more willing to lend them money, favoring the existence of contracts (Chiriboga et al., 2007). Gómez et al. (2007) found that the farm area is positively related to the use of CF because agribusiness firms desire high-volume production. With respect to the types of products that farms produce, the firms can define the products and the production systems, or the farmers can determine what to produce and then the agribusiness firms buy the production through contracts (as is the case in Chile). In both cases, the use of CF provides the framework for producing high-value crops, such as those products oriented for the export market (Masakure and Henson, 2005; Heri, 2000, Milocevic et al., 1999). Lastly, the effect of neighboring producers that use contracts is an out-of-farm element that also influences the adoption of CF. In fact, as with any adoption process, some leader farmers using contracts can influence other farmers to adopt contracts (Feder and Savastano, 2006). 
Despite previous research that has identified the factors that influence the use of $\mathrm{CF}$, the particular cultural, legal, productive and economic environment in which the contracts are settled are unique to each zone or country. Thus, the objective of this study was to analyze the factors that influence the use of contract farming by southern Chilean farmers. It is important to note that although "adoption" implies that a farmer has decided to use contracts on a permanent basis, and "use" represents the presence of contracts at a given moment, most farmers involved in this research declared that they have used contracts for a long time, so these terms are used interchangeably in this paper. The results derived from this research can be very useful in the design of public policies that are intended to promote the use of $\mathrm{CF}$ and indirectly strengthen the agricultural export activity of the country. To the best of our knowledge, this is the first study conducted in Chile in which the determinants of the use of CF has been analyzed using data collected at the individual farmer and farm levels.

\section{Materials and methods}

\section{Quantitative method}

The use of CF can be modeled using a discrete choice model (Long, 1997) to reflect whether farmers choose to reach agreements (either written or oral) with agribusiness firms to establish conditions for the production and marketing of their products or choose to produce and sell their products without having contracts (a no-contract situation).

Assume that there are two contractual choices, $\mathrm{Z}$ and $\mathrm{W}$, where the utility associated with $\mathrm{Z}$ is $u_{Z}$ and the utility associated with $\mathrm{W}$ is $u_{W}$. A farmers chooses the contractual alternative $\mathrm{Z}$ when $u_{Z}>u_{W}$ and chooses $\mathrm{W}$ when $u_{W}>u_{Z}$. Assume that $u_{Z}=u_{W}$ does not happen and that farmers maximize their utility. A farmer $i$ who chooses $Z$ receives a utility $\mu_{i Z}$, which is also associated with a random error $\varepsilon_{i Z}$. That is, $u_{i Z}=\mu_{i Z}+\varepsilon_{i Z}$. If the farmer chooses $\mathrm{Z}$, then $u_{Z}>u_{W}$ must hold. Therefore:

$$
\operatorname{Pr}\left(y_{i}=Z\right)=\operatorname{Pr}\left(u_{i Z}>u_{i W}\right)=\operatorname{Pr}\left(\mu_{i Z}+\varepsilon_{i Z}>\mu_{i W}+\varepsilon_{i W}\right)
$$

If there are $\mathrm{J}$ alternatives, the probability that farmer $i$ chooses alternative $m$ is:

$$
\operatorname{Pr}\left(y_{i}=m\right)=\operatorname{Pr}\left(u_{i m}>u_{i j} \text { for all } j \neq m\right)
$$

Assuming a logit distribution of the error term, $\varepsilon$, a multinomial logit (MNL) model can be stated as follows:

$$
P\left(y_{i}=m \mid x_{i}\right)=\frac{\exp \left(x_{i} \beta_{m}\right)}{1+\sum_{j=2}^{J} \exp \left(x_{i} \beta_{j}\right)}, \text { for } m>1
$$

where the probability $P\left(y_{i}=m\right)$ that farmer $i$ chooses any of the three contractual options, i.e., no contractual relation, oral contracts, or written contracts, is based on the linear combination $x_{i} \beta_{m}$, an average utility of $\mu_{i m}$. The vector $x$ represents farmer attributes, farm characteristics, and outof-farm elements, and $\beta$ is the associated vector of coefficients (note that a category $J$ is dropped from the equation to identify the model).

The estimation of equation (3) provides information on the direction and significance level of the variables. Hence, marginal and discrete changes are calculated to evaluate the magnitudes of the effects. In this way, binary variables are analyzed using discrete changes (0 to 1 ), and continuous variables are examined as marginal effects, changes in their range (minimum to maximum values) and changes of one unit. Moreover, given that the marginal and discrete changes depend on the value at which each variable is evaluated, odds ratios (factor change coefficients) are also examined. Additionally, predicted probabilities are used to analyze the combined effect of relevant variables.

The data used in this quantitative method were obtained from face-to-face questionnaires given to a random sample of farmers from the Araucanía and 
Los Ríos regions. The sample was geographically stratified to represent most of the counties in each region. Based on the differences in the use of contracts between export-oriented producers (exporters) and those that produce mainly for the internal market (commonly called traditional producers), the sample included both type of farmers. Because there are few producers of exportables in these regions, for each producer of exportables who participated in the study, a producer of nonexportables was selected in the surrounding area. Thus, using a snowball sampling technique, a total of 384 producers were selected and interviewed.

To be consistent with the literature, the questionnaire included variables related to the farmer, the farm and out-of-farm aspects. Although it was originally intended that agribusiness firms would be surveyed for this study, most of them refused to participate in the study. The farmers' variables were age, gender, educational level (years of formal education) and risk perception. With respect to the last of these, farmers were classified in three categories: risk-averse, risk-neutral and risk-seeking individuals. One of the farm-related variables was the land tenure system, which considered three categories: owner, renter and other land tenure. Other farm-related variables included the farm area (in hectares) and the farm production type (internal or external market orientation). The out-of-farm variable considered was the effect of neighboring producers using contracts. The value of this variable was calculated in two ways: as the geographic concentration of farmers with either oral or written contracts in a specific county (contracts' concentration) and as the geographic concentration of farmers with written contracts only (written contracts' concentration). Table 1 shows the descriptive statistics associated with these variables.

\section{Qualitative method}

The categorical specification of the MNL model permitted the analysis of the determinants involved in the use of CF. However, this discrete choice model is based on the concept that there are unobservable variables that influence the producers to adopt or not adopt the CF system. Therefore, we used an additional methodological approach that made it possible to understand the factors underlying the decisions of producers to use contracts (Sechrest and Sidani, 1995). Once the survey data were analyzed, qualitative research instruments were used to complement the results obtained from the MNL model.

Table 1. Descriptive statistics of variables used in the quantitative method.

\begin{tabular}{lllll}
\hline Variables & Mean & SD & Minimum & Maximum \\
\hline Age (years) & 52.350 & 13.966 & 19 & 91 \\
Gender & 0.586 & 0.493 & 0 & 1 \\
Educational level (years) & 9.380 & 3.978 & 0 & 18 \\
Risk-averse & 0.307 & 0.462 & 0 & 1 \\
Risk-neutral & 0.158 & 0.365 & 0 & 1 \\
Risk-seeking & 0.535 & 0.499 & 0 & 1 \\
Production type (exportables=1) & 0.266 & 0.442 & 0 & 1 \\
Farm area (hectares) & 30.970 & 75.690 & 0.008 & 650 \\
Owner & 0.774 & 0.418 & 0 & 1 \\
Renter & 0.092 & 0.289 & 0 & 1 \\
Other land tenure & 0.133 & 0.340 & 0 & 1 \\
Contracts' concentration & 0.063 & 0.063 & 0 & 0.225 \\
Written contracts' concentration & 0.058 & 0.068 & 0 & 0.225 \\
\hline
\end{tabular}

SD: Standard Deviation. 
Two instruments were used to collect qualitative data: focus groups and in-depth individual interviews. The focus group method consists of group interviews in which the participants were allowed to interact and talk about a specific topic (McLafferty, 2004). Two focus group meetings were conducted in each region. The participating producers (traditional producers and exporters) were selected based on their experience with the use of contracts in their respective areas. The discussion focused on the factors that producers considered important or relevant in generating contractual linkages among producers and agribusiness firms. The in-depth individual interviews consisted of personal interviews of a small number of people to explore their perspectives on a particular idea or situation (Boyce and Neale, 2006). In this study, in-depth individual interviews were carried out with twelve professionals and officials of public institutions in both regions to capture their perceptions about $\mathrm{CF}$, particularly its importance for the economic development of the agricultural sector, their opinions about the use of $\mathrm{CF}$, and the concrete actions these institutions are taking toward supporting this theme. The results of the focus group meetings were analyzed using a relational matrix and the results of the in-depth interviews were subjected to a content analysis.

\section{Results and discussion}

The econometric analysis of the factors underlying the decision to use contracts demonstrated an important effect of the geographic concentration of producers using contracts in a specific location. Thus, two models were examined. In the first model, this effect was assessed for both oral and written contracts (the variable contracts' concentration), and in the second model, this effect was assessed for written contracts only (the variable written contracts' concentration). The analysis showed that the models were not significantly different. Therefore, we present only the results obtained for the second model. Moreover, a test of the independence of irrelevant alternatives (IIA) assumption showed that the three categories of contracts (oral, written and no contracts) are independent, which validates the use of the MNL approach.

Table 2 shows the estimation of the MNL model. The first and second columns show the estimates of the MNL using the no-contracts alternative as the base category, and the third column compares the alternative of using written contracts with the alternative of using oral contracts. The first important result is that the roles of the selected variables are different for the three alternatives. The only farmer-specific characteristic that was found to be statistically significant with respect to the use of oral contracts instead of not using contracts (the first column) was gender, i.e., men are more likely to adopt oral contracts than women. Among the farm-related attributes, renter, farm area, and production type were found to have positive and significant effects on the use of oral contracts. Contrary to what is reported in the literature (Chiriboga et al., 2007), farmers who rent land (and not those who own it) are more likely to use oral contracts. Although there is not enough evidence to explain this with certainty, it is possible that producers of high-value products (mainly exportables linked to CF) are mostly entrepreneurs who would be willing to begin production by renting land. With respect to the farm size, the probability of a producer using oral contracts increases with the size of the farm he or she operates, which is consistent with the results reported by Anim (2011). Indeed, a larger farm is desirable for agribusiness firms because having many small suppliers means higher trading costs (Gómez et al., 2007). The production type variable shows that the production of exportables is positively related to the use of contracts because a formal agreement (at least an oral agreement) has to be established to sell the products on the export market. This has also been observed in other countries (Masakure and Henson, 2005). Finally, the written contracts' concentration variable has a positive and significant effect on the use of oral contracts. This indicates that 
producers that are located in an area where most of their neighbors have written contracts with agribusiness firms (regardless of the type of product they grow) are more likely to use contracts. This result shows that the use of CF could respond to an innovation adoption process, and hence, the influence of leaders in the use of CF could induce the adoption of contracts by other farmers (Feder and Savastano, 2006).

A comparison between the written-contract alternative and the no-contract alternative (the second column) shows that among the farmerspecific characteristics, the only variable relevant to this choice is the producer's educational level. Previous research (Anim, 2011; Singh, 2002) has also shown that the use of written contracts most likely requires a deeper understanding and knowledge of the legal and commercial obligations and rights that a producer would be willing to accept if he or she signs an agreement with an agribusiness firm. Thus, producers with less education are less likely to use written contracts. Among the farm-related elements, as in the case of oral contracts, the exportable production and the farm area are factors that positively affect the decision to use written contracts rather than not use contracts.

Table 2. Factors determining CF analyzed using a multinomial logit model.

\begin{tabular}{|c|c|c|c|}
\hline & $\begin{array}{l}\text { Oral contracts vs. } \\
\text { No contracts }\end{array}$ & $\begin{array}{l}\text { Written contracts vs. } \\
\text { No contracts }\end{array}$ & $\begin{array}{l}\text { Written contracts vs. } \\
\text { Oral contracts }\end{array}$ \\
\hline \multirow[t]{2}{*}{ Age } & 0.011 & 0.012 & 0.002 \\
\hline & $(0.014)$ & $(0.021)$ & $(0.018)$ \\
\hline \multirow[t]{2}{*}{ Gender } & $1.018^{1}$ & 0.926 & -0.091 \\
\hline & $(0.404)$ & $(0.592)$ & $(0.502)$ \\
\hline \multirow{2}{*}{ Educational level } & 0.078 & $0.186^{1}$ & 0.108 \\
\hline & $(0.050)$ & $(0.073)$ & $(0.061)$ \\
\hline \multirow[t]{2}{*}{ Production type (exportables) } & $4.745^{1}$ & $5.934^{1}$ & $1.189^{1}$ \\
\hline & $(0.619)$ & $(0.803)$ & $(0.577)$ \\
\hline \multirow[t]{2}{*}{ Risk-averse } & -0.246 & -0.679 & -0.433 \\
\hline & $(0.531)$ & $(0.808)$ & $(0.690)$ \\
\hline \multirow[t]{2}{*}{ Risk-seeking } & -0.296 & -0.161 & 0.135 \\
\hline & $(0.503)$ & $(0.701)$ & $(0.571)$ \\
\hline \multirow[t]{2}{*}{ Farm area } & $0.008^{1}$ & $0.015^{1}$ & $0.006^{1}$ \\
\hline & $(0.004)$ & $(0.004)$ & $(0.002)$ \\
\hline \multirow[t]{2}{*}{ Owner } & 1.498 & 2.057 & 0.559 \\
\hline & $(0.748)$ & $(1.280)$ & (1.163) \\
\hline \multirow[t]{2}{*}{ Renter } & $2.498^{1}$ & 2.564 & 0.067 \\
\hline & $(0.915)$ & $(1.492)$ & $(1.304)$ \\
\hline \multirow[t]{2}{*}{ Written contracts' concentration } & $9.993^{1}$ & $14.019^{1}$ & 4.026 \\
\hline & $(2.935)$ & $(3.733)$ & $(2.637)$ \\
\hline \multirow[t]{2}{*}{ Constant } & $-5.804^{1}$ & $-10.008^{1}$ & -4.203 \\
\hline & $(1.309)$ & $(2.036)$ & $(1.739)$ \\
\hline Number of observations & 368 & & \\
\hline Log-likelihood value & -174.80 & & \\
\hline Pseudo $\mathrm{R}^{2}$ & 0.47 & & \\
\hline
\end{tabular}

${ }^{1}$ Significant at $5 \%$.

Numbers in parentheses are Standard Deviations. 
A comparison between the written-contract alternative and the oral-contract alternative shows that the production of exportables and the farm area (variables related to production) are the only factors that are relevant to the choice to use oral contracts. It is likely that the relationship between large exporting farms and agribusiness firms is based on mutual trust, where neither of the two parties is willing to assume the costs of not honoring the agreement, such as the loss of reputation among other exporting firms or large farmers. Most likely, this situation would not be the same for a small farmer, who would feel more protected if he or she had a written contract.

As mentioned previously, the results obtained from the MNL model only provide information on the significance level and direction of the coefficients, not their magnitudes. For this reason, marginal and discrete changes were calculated. This analysis showed that among the binary variables, exportable production (as opposed to domestic production) has the greatest effect. In fact, the production of exportables increases the probability of using oral and written contracts by 0.6 and 0.21 , respectively. Among the continuous variables, the geographic concentration of producers with written contracts in a specific county has the greatest effect. Thus, the probabilities that a farmer who is located in a county with a high concentration of written contracts will use oral or written contracts increase by 0.39 and 0.13 , respectively.

Because of space constraints, we do not present the entire set of marginal and discrete changes. Instead, for simplicity, we present a graphical analysis of the odds ratios (factor change coefficients), which offers the advantage of providing information about the magnitude of the effects without considering the value at which each independent variable is analyzed. Figure 1 presents odds ratios for the variables that were statistically significant in the MNL model. The letters represent the three alternatives (no contracts, N; oral contracts, $\mathrm{O}$; and written contracts, W). For each variable, the effects on the alternatives that were not significantly different are enclosed in a box. It should be noted that the only variables that have an effect significantly different from not having contracts $(\mathrm{N})$ are the farmer's educational level, the farm area, the production of exportables, and the concentration of written contracts (although in this case there is no difference between choosing oral or written contracts). However, the last two variables have the greatest effects in terms of magnitude.

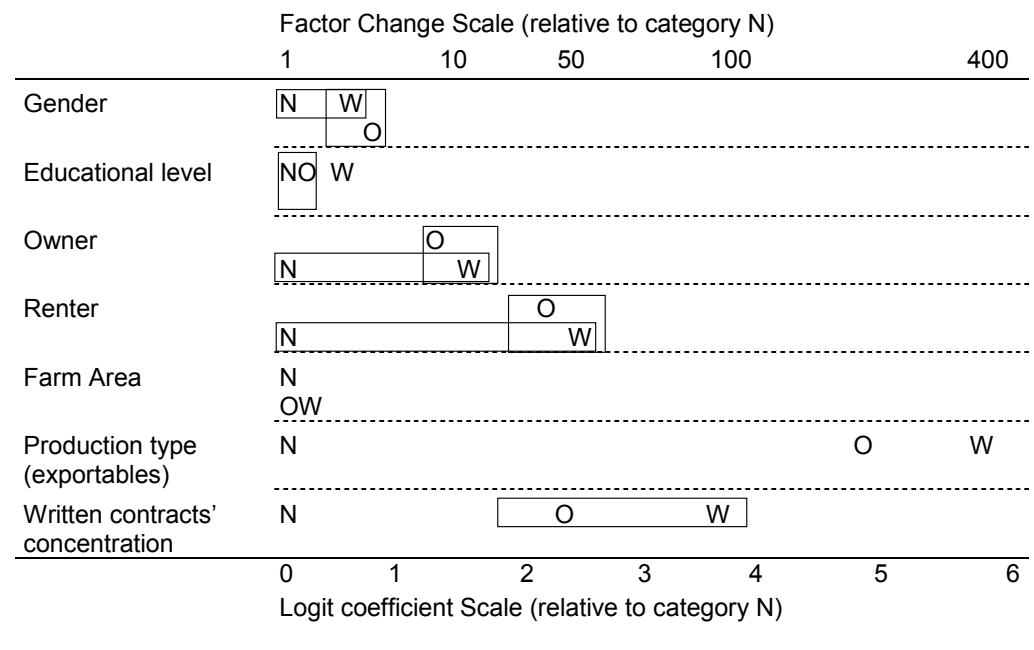

Figure 1. Odd ratios plot derived from the multinomial logit model. W: written contracts; O: oral contracts; N: no contracts. 
Despite the results of the analysis described above, it is difficult to compare the effects of variables that are of the binary type (e.g., production type) with those that are continuous (e.g., written contracts' concentration). Thus, Figure 2 shows predicted probabilities that allow a comparison of the relevant variables for different levels of their range. Given the importance of the production type variable, case (a) of Figure 2 shows the case of a farmer who produces only exportables, and case (b) shows the case of a farmer who produces only for the internal market (traditional products). In both cases, there is a combination of 3 variables: educational level, written contracts' concentration and the farm area. As a result, in both cases, a and $b$, there can be several combinations. For convenience and simplicity, we used educational level as the $x$-axis and arbitrarily chose the levels at which the variables were evaluated. Producer 1 in case (a) represents a farm that produces exportables, has a size of 100 ha and is located in a county where there is a high (maximum) concentration of farmers with written contracts. We call this combination $(1,100, \max )$. On the other hand, Producer 1 of case (b) has a farm that produces traditional products, that is $5 \mathrm{ha}$, and that is located in a county where there are no written contracts, i.e., the combination $(0,5$, min). Using this nomenclature, in case (a) we have Producer 1 (1, 100, max), Producer $2(1,5, \mathrm{~min})$, Producer 3 $(1,5, \max )$, and Producer $4(1,100, \mathrm{~min})$. In case (b) we have Producer $1(0,100, \max )$, Producer 2 $(0,5, \min )$, Producer $3(0,5, \max )$, and Producer $4(0,100, \mathrm{~min})$.

The comparison of all of the situations depicted in Figure 2 demonstrates an important result: despite the effect of each variable on the use of contracts, it is the combination of them that results in the highest probability of using written contracts. A farmer who has the characteristics of Producer 1 in case (a) has a probability of approximately $70 \%$ of using written contracts when he or she has the highest level of formal education. On the other hand, a farmer who has the characteristics of
Producer 2 in case (b), with no formal education, has little probability of using written contracts.

Complementing these results, the qualitative analysis provided a deeper understanding of the processes underlying the factors that influence the farmers' contract choice. The focus groups indicated that the most important factor in the generation of contractual linkages with agribusiness firms is "associativity," understood by farmers as the joint efforts made by individuals to help each other to solve their problems and meet their needs. Indeed, associativity gives farmers greater bargaining power with agribusiness companies because they can offer their production as if it were one large-scale production unit (Kirsten and Sartorius, 2002; Anim, 2011). It is likely that the dynamic interaction among members of an association spreads the use of contracts from some members to others, which is consistent with the findings of the quantitative analysis, namely, the effect of the geographic concentration of farmers with contracts. The other two factors that the individuals reported as relevant to the decision to use contracts were the technical assistance provided by firms and the farmers' educational level. Farmers expressed the view that because of the importance that firms place on product quality, contracts give farmers access to technical support for which they would otherwise have to pay. Similar results have been reported in other studies (Anim, 2011). Although this technical assistance is particularly influential in the production of exportables, these results show that the technical support related to the production of internal-market products could also be an important determinant in the use of contracts. With respect to education, farmers expressed the view that education is very important in settling contracts because having a higher educational level provides a better understanding of the terms of the agreement and their consequences, which is consistent with the results of the quantitative analysis and in the results of other studies (Miyata, 2009). 

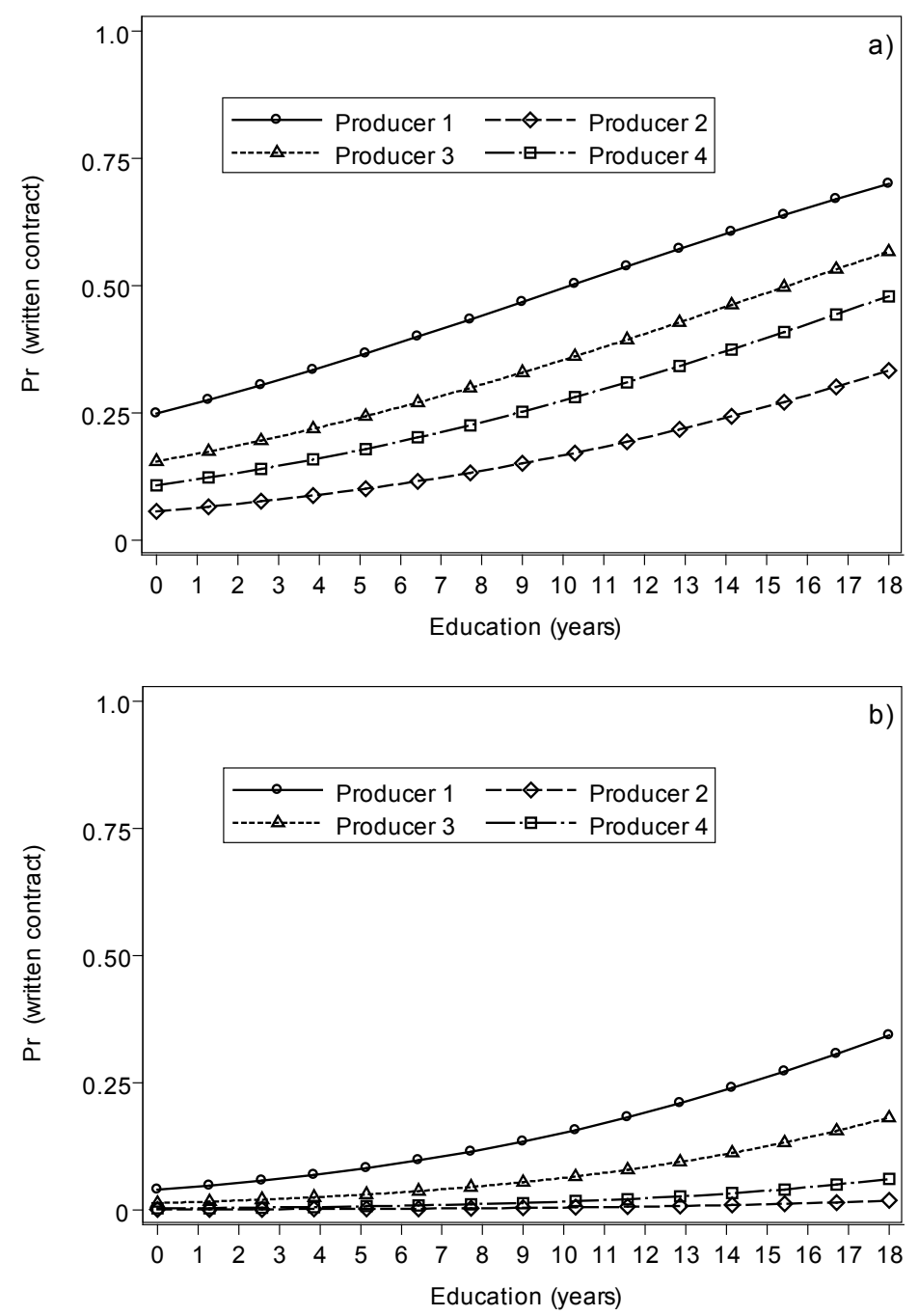

Figure 2. Predicted probabilities for (a) Producer of exportables, and (b) Producer of traditional products.

The results of the in-depth interviews showed that $\mathrm{CF}$ is perceived as important to the productive development of the two regions considered in this study, mainly because through contracts, small producers can obtain better guarantees of their production (prices and a market where they can trade their products). Furthermore, small producers consider the use of CF as desirable, even though it is hardly widespread in the agricultural sector. The interviewees also indicated that there are no specific national policies that support the use of the CF system. There is only a small governmental initiative that is intended to contribute to the development of a CF system. However, the interviewees noted that in this program, the government only seeks to establish links between producers and companies; it does not review agreements or involve itself in the delivery, payment or price terms of the contracts. The limited action taken by public institutions regarding $\mathrm{CF}$ is consistent with the low use of $\mathrm{CF}$ in southern Chile.

In conclusion, this study has shown that there is a strong association between the use of contracts and the individual effects of a farmer's educational 
level, the market-production orientation of his or her farm and the concentration of neighboring producers who use contracts. However, when these elements interact with others (the farm size, the presence of organizations, and the need for technical assistance) the use of CF is affected significantly. Thus, a producer with a high educational level, a large farm, and a production oriented toward the export market, who is located in an area with a high concentration of neighbors using $\mathrm{CF}$, who belongs to organizations, and who needs technical assistance from agribusiness firms is highly likely to use CF. However, it should be noted that a positive relationship between risk-averse farmers and the use of contracts was not detected in this study. Both theoretical and empirical studies (Key and McBride, 2003; Goodhue, 1999) have shown that one of the great advantages of $\mathrm{CF}$ is that it helps farmers to reduce the risk of their transactions. Thus, this could be a sign of a problem in the way that farming contracts are established in southern Chile, specifically the clauses they contain, wherein it may not be clear what benefits farmers should receive.

\section{Acknowledgements}

This research is part of FONDECYT Project N¹1100228.

\section{Resumen}

L. Morales, R. Echeverría y M. Barrera. 2013. Factores que determinan el uso de la agricultura por contrato en agricultores del sur de Chile. Cien. Inv. Agr. 40(1):43-53. A diferencia de la zona central, en la zona sur de Chile la Agricultura por Contrato (AC) es muy poco utilizada, y existen pocos estudios que permiten explicar esta situación. En este contexto, el objetivo de este estudio fue analizar los factores que determinan el uso de la $\mathrm{AC}$ en el sur de Chile. La metodología consideró dos enfoques de investigación complementarios: uno cuantitativo, en donde se aplicó un análisis logístico multinomial utilizando datos provenientes de cuestionarios aplicados a 384 productores de la zona sur, y uno cualitativo, donde se realizaron entrevistas en profundidad a profesionales y funcionarios de instituciones públicas y grupos focales a productores. Los principales resultados muestran que aquellos productores que tienen un mayor nivel educacional, con predios de mayor tamaño, con una producción orientada al mercado externo, que se ubican en zonas con una alta concentración de vecinos que usan contractos, que pertenezcan a asociaciones y que necesiten asistencia técnica por parte de las empresas compradoras, tienen mayores probabilidades de usar el sistema de AC. Sin embargo, a pesar del efecto individual de cada uno de estos factores, es el efecto combinado de ellos el que está más asociado al uso de la AC. Además, la falta de una relación positiva entre los agricultores adversos al riesgo y el uso de contratos podría ser una señal de una falla en la manera en que los contractos son establecidos en el sur de Chile.

Palabras clave: Agricultura por contrato, multinomial logístico, grupos focales, entrevistas. 


\section{References}

Anim. F. 2011. Small-scale maize farmers' decision to participate in contract farming: Implications for integration into the marketing chain. African Journal of Business Management 5: 5065-5069.

Boyce, C., and P. Neale. 2006. Conducting in-depth interviews: A guide for designing and conducting in-depth Interviews for evaluation input. Pathfinder International Tool Series. Monitoring and Evaluation 2, Pathfinder International, USA. p. 3-11.

Chiriboga, M., C. Chehab, E. Vazquez, V. Salgado, and O. Recalde. 2007. Mecanismos de articulación de pequeños productores rurales a empresas privadas PPR-EP. Informe Nacional Ecuador Rimisp. Plataforma Regional Andina. Quito, Ecuador. p. 7-64.

Da Silva, C. 2005. The growing role of contract farming in agri-food systems development: drivers, theory and practice. Agricultural Management, Marketing and Finance Service FAO. p. 11-15.

Eaton, C., and A. Shepherd. 2001. Agricultura por Contrato: Alianzas para el crecimiento. Servicios Agrícolas FAO. Roma, Italia. p. 1-119.

Feder, G., and S. Savastano. 2006. The role of opinion leaders in the diffusion of new knowledge: the case of integrated pest management. World Development 34:1287-1300.

Gómez, S., J. Echenique, and G. Jordan. 2007. Articulación pequeña agricultura y agroindustria el caso de Chile. Fundación Chile. Santiago, Chile. 83 pp.

Goodhue, R. E. 1999. Input control in agricultural production contracts. American Journal of Agricultural Economics 81:616-620.

Guo, H., R. Jolly, and J. Zhu. 2007. Contract farming in China: perspectives of farm households and agribusiness firms. Comparative Economic Studies 49:285-312.

Heri, S. 2000. The growth and development of the horticultural sector in Zimbabwe. Paper prepared for the UNCTAD Conference. Geneva, Switzerland. p. 2-32.

INE. 2007. VII Censo agropecuario y forestal. Instituto Nacional de Estadísticas (INE).
Santiago, Chile. Available online at: http://www. censoagropecuario.cl/ (Website accessed: March 24, 2011).

Key, N., and W. McBride. 2003. Production contracts and productivity in the US Hog Sector. American Journal of Agricultural Economics 85:121-133.

Kirsten, J., and K. Sartorius. 2002. Linking agribusiness and small-scale farmers in developing countries: is there a new role for contract farming? Development Southern Africa 19:503-519.

Long, S.J. 1997. Regression models for categorical and limited dependent variables. $7^{\text {a }}$ Edition. Thousand Oaks: Sage Publications Inc. USA. 328 pp

McLafferty, I. 2004. Focus group interviews as a data collecting strategy. Journal of Advanced Nursing 48:187-194.

Masakure, O., and S. Henson. 2005. Why do small scale producers choose produce under contract? Lessons from nontraditional vegetable exports from Zimbabwe. World Development 33:1721-1733.

Milocevic, X., J. Berdegué, and T. Reardon. 1999. Impactos de los encadenamientos de la agricultura de contrato con agroindustrias: El caso del tomate en Chile. Food and Agriculture Organization of the United Nations (FAO), Santiago, Chile. 42 pp.

Miyata, S., N. Minot, and D. Hu. 2009. Impact of contract farming on income linking small farmers, packers, and supermarkets in China. World Development 37:1781-1790.

Prowse, M. 2012. Contract farming in developing countries - a review. Available online at http:// www.afd.fr/a-savoir (Website accessed: March 12, 2012).

Singh, S. 2002. Contracting out solutions: political economy of contract farming in the Indian Punjab. World Development 30:1621-1638.

Sechrest. L., and S. Sidani. 1995. Quantitative and qualitative methods: is there an alternative? Evaluation and Program Planning 18:77-87.

Vermeulen, S., and L. Cotula. 2010. Making the most of agricultural investment: A survey of business models that provide opportunities for smallholders. Food and Agriculture Organization of the United Nations (FAO) and the International Institute for Environment and Development (IIED), London/Rome/Bern. 106 pp. 
